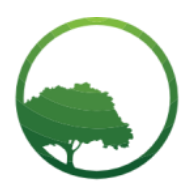

Research in Business \& Social Science

IJRBS VOL 9 NO 2 ISSN: 2147-4478 IJRBS

Available online at www.ssbfnet.com Journal homepage: https://www.ssbfnet.com/ojs/index.php/ijrbs

\title{
Effect of tax penalties, tax audit, and taxpayers awareness on corporate taxpayers' compliance moderated by compliance intentions
}

\author{
Nida Putri Rahmayanti $@_{a}$, Sutrisno T $b$, Yeney Widya Prihatiningtias $\bigotimes_{c}$ \\ a,b,c Accounting Department, Brawijaya University, Indonesia
}

Crossref

\begin{tabular}{l} 
A R T I C L E I N F O \\
\hline Article history: \\
Received 01 Feb 20 \\
Received in revised form 13 Feb 20 \\
Accepted 18 Feb 20 \\
\hline Keywords: \\
Penalty Sanctions, Tax examination \\
Taxpayer awareness, Obedient \\
intentions, Corporate taxpayer \\
Compliance. \\
JEL Classification: \\
H20, H21
\end{tabular}

\begin{abstract}
A B S T R A C T
This study aims to empirically examine the impact of tax penalties, tax audits, and taxpayers' awareness of corporate taxpayer compliance and the role of compliant intentions as the moderating variable in its correlation. The analytical method used is the Multiple Linear Regression (Multiple Regression Analysis) and the Moderated Regression Analysis (MRA). The population of this study is the corporate taxpayers in North Banjarmasin Tax Office in 2019 with a sample of 142 corporate rate taxpayers. The sampling method used is convenience sampling. The results show that tax penalties, tax audits, and taxpayers' awareness positively affect corporate taxpayer compliance. However, the compliant intention is unable to moderate the effect of fines, tax audits, and taxpayers' awareness toward corporate taxpayer compliance. This is due to the applied penalties and tax audits following the taxation laws and the corporate taxpayer's awareness of the importance of taxation as the source of state income. The purposes of this research are to provide inputs and references for the tax authorities and taxpayers, to examine further about tax penalties and tax audits that have been implemented, and to raise awareness among taxpayers for complying with taxes. Then, this research is influenced by external factors and internal factors, namely penalty sanctions, tax audits, and awareness of taxpayers who make taxpayers compliant with taxes, so that the presence or absence of intentions will continue to make taxpayers obedient to taxes. (C) 2020 by the authors. Licensee BSC International Publishing, Istanbul, Turkey. This article is an open access article distributed under the terms and conditions of the Creative Commons Attribution (CC BY) license (http://creativecommons.org/licenses/by/4.0/).
\end{abstract}

\section{Introduction}

Taxpayers' compliance is one of the obligations of Indonesian citizens. Tax becomes the largest revenue sector of the state treasury. The revenue from the tax sector plays a critical role in the sustainability of the government system in a country. The absence of tax will bring difficulties in prospering and developing society. The level of tax compliance can be seen from the tax ratio. In 2018, the tax ratio only reached $10.3 \%$, below the target of $11 \%$ as stipulated in the 2018 State Budget Financial Note. ASEAN countries, such as the Philippines, Singapore, Laos, Thailand and Malaysia have higher tax ratios compared to Indonesia. Therefore, the problem is that many people are still not compliant with taxes. In other words, the results of the percentage above indicate that in Indonesia, the level of tax compliance is low. As a result, state or regional income from taxes is low and the infrastructure is underdeveloped.

Taxpayer compliance is one of the obstacles in the effectiveness in collecting tax. To achieve tax target, the taxpayer must know that there are sanctions in the taxation namely sanctions (administrative). Taxpayers will comply with taxes if the sanctions will be more detrimental. The more remaining tax arrears that must be paid by taxpayers, it is harder for taxpayers to pay off the obligations. Therefore, it is important to research tax penalties (fines) in tax laws to assist the government in raising public awareness about taxpayer compliance.

Another factor besides the penalty that is considered to make taxpayers afraid to violate taxation rules is tax audits (Oladipupo \& Obazee, 2016). The purpose of tax audits to examine tax compliance is something that must be implemented. To provide legal clarity, the type of examination, the period in carrying out the examination, and other procedures for the examination are done following the applicable laws. Besides the existence of financial penalties and tax audits from the external factors, awareness from within the taxpayer himself is also needed.

* Corresponding author. ORCID ID: 0000-0001-5205-0761

(C) 2020 by the authors. Hosting by SSBFNET. Peer review under responsibility of Center for Strategic Studies in Business and Finance. https://doi.org/10.20525/ijrbs.v9i2.633 
Taxpayer awareness means that when taxpayers realize, and obey all applicable tax provisions and have the desire to comply with taxes (Muhamad, 2019). Awareness to pay taxes is the behavior of taxpayers in the form of a person's views based on the knowledge they have accompanied by reasoning to behave following applicable tax provisions (Erani \& Meiliana, 2016). Besides the awareness of taxation which arises from within the taxpayer, there must also be an intention that comes from someone then the taxpayer will behave obediently or not towards taxation. This research refers to the TRA which later developed as TPB is related to individual behaviors (Ajzen \& Driver, 1992).

\section{Literature Review}

According to previous researches related to taxpayers compliance, there are several factors that can make taxpayers comply with the applicable tax regulations, some of them are financial penalties, tax audits, tax awareness, and compliant intention (Budiartha \& Ketut, 2019) ; (Arifin \& Syafii, 2019); (Al- Maghrebi, Ahmad, \& Palil, 2016); (Erani \& Meiliana, 2016). This research is based on motivation that (1) taxpayer compliance in Indonesia is still low, (2) inconsistencies in the results of previous studies related to taxpayer compliance, and (3) this study refers to research abroad using Theory of Reasoned Action (TRA) and Attribution Theory that will be applied by taxpayer compliance in Indonesia. Therefore, this research will apply the theory in Indonesia. Based on data from the Directorate General of Taxes, the tax ratio in 2018 is still far below the target of $11 \%$ and in 2019 the tax target will only reach $11.6 \%$ below the target of $12.2 \%$.

In addition, Indonesia compared to other ASEAN countries has the lowest tax ratio. The data shows that the still low compliance of taxpayers in Indonesia (Keuangan, 2018). The renewal of this study uses the variable sanctions fines, tax audits, and awareness of taxpayers and add the intention to comply as a moderating variable based on recommendations from previous studies. Then, this study uses 2 theories, namely Theory of Reasoned Action (TRA) to explain the submissive intention and behavior of individuals to comply or not comply with taxes, and the Attribution Theory to explain external factors (penalties and tax audits) and internal factors (compulsory awareness tax) to corporate taxpayer compliance. Thus, the purpose of this study is to foster the intention of taxpayer compliance and awareness of taxpayers to pay taxes on time voluntarily.

\section{Penalty sanctions}

Research by (Erani \& Meiliana, 2016); (Siamena, Sabijono, \& Warongan, 2017); (Siregar, 2017) show that tax penalties in the form of fines affect taxpayer compliance. It is because of the realization of respondents that tax is a source of state revenue in financing state needs up to public facilities and infrastructure, in which it has increased the level of tax compliance in financing the state. Therefore, if the imposition of tax penalties is executed regularly and in an orderly manner, tax penalties will increase the compliance of the corporate taxpayers themselves. In this case, attribution theory is related to tax penalties, because the behavior is caused externally, or behavior that is influenced from outside. Thus, the tax penalties in the form of fines have an important role in providing lessons for those who violate taxation rules and taxpayers will comply with taxes if the sanction is more inflicting the financial loss. The results of previous studies and the logical thinking that has been explained above, the hypothesis that can be formulated is:

$\mathrm{H}_{1}$ : tax penalties have a positive effect on corporate taxpayer compliance.

\section{Tax examination}

State that tax audits affect taxpayer compliance (Widuri et al., 2019). The results explain that a tax audit which is done routinely will increase corporate taxpayer compliance because these audits will minimize the level of fraud committed by taxpayers and create a deterrent effect for the offenders. In this study, the tax audit variable is explained in the attribution theory. Tax audits conducted by the tax authorities as an external party can influence the behavior of the. The more routine supervision is carried out towards taxpayers, the greater the effect of tax audits on corporate taxpayer compliance. Based on the results of previous studies and logical thinking that has been explained above, the hypothesis that can be formulated is:

$\mathrm{H}_{2}$ : Tax audit has a positive effect on corporate taxpayer compliance.

\section{Taxpayer awareness}

Furthermore, Research of (Adhiambo \& Theuri, 2019); (Bernard, Memba, \& Oluoch, 2018); (Savitri \& Musfialdy, 2016); and (Kamil, 2015) explain that taxpayer awareness influences taxpayer compliance. Awareness of taxpayers is that taxpayers know the procedures for implementing tax provisions correctly. If the taxpayer is aware of the importance of taxes and the procedures for implementation taxation, it can increase tax compliance (Kamil, 2015). In this study, the taxpayer awareness variable is explained in the attribution theory as an internal factor. Because before individuals do something, the individual will have confidence in the results that will be obtained. Then, the person will decide whether to do it or not. The results of previous researches and logical thinking that has been explained above, the hypothesis that can be formulated are:

$\mathrm{H}_{3}$ : Taxpayer awareness has a positive effect on corporate taxpayer compliance.

\section{Obedient intentions}


Furthermore, (Oktaviani \& Nurhayati, 2015) 's research explains that intention affects taxpayer compliance. The intention is interpreted as an instruction given by an individual to himself to perform a certain behavior (Wanarta \& Mangoting, 2014). It is also closely related to the motivation that exists in a person consciously or unconsciously to take any action with a certain goal. The intention in the TRA model explains that intention which arises to do something following existing regulations will generate the right behavior and not detrimental to someone (Ajzen, 2002). The relation of intention in this research is to strengthen the effect of tax penalties, tax audits, and taxpayer awareness on corporate taxpayer compliance. Based on the results of previous studies and logical thinking that have been explained above, the hypothesis that can be formulated is:

$\mathrm{H}_{4}$ : Compliance intention to strengthen the positive effect of fines sanctions on corporate taxpayer compliance

H5: Compliance intention to strengthen the positive effect of tax audits on corporate taxpayer compliance

H6: Compliance intention reinforces the positive influence of taxpayer awareness on corporate taxpayer compliance

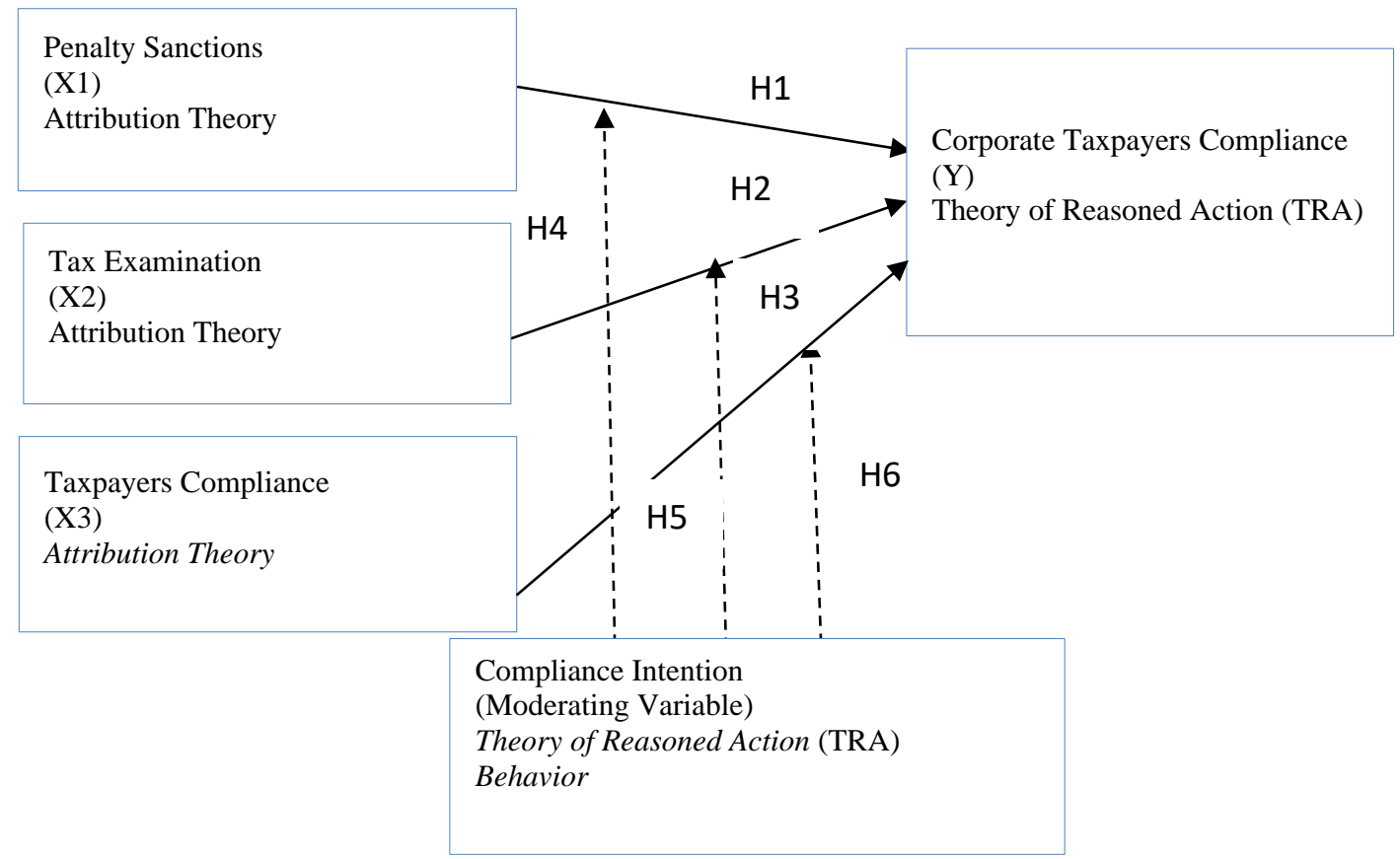

Fig. 1: Research Model

\section{Research and Methodology}

This study used a quantitative approach based on a positive paradigm and examined the variables that affect tax compliance. It focused on the effect of tax penalties, tax audits and taxpayer awareness on corporate taxpayer compliance using moderation variables, namely compliance intention. Additionally, this research is explanatory in which it is organized on two to more constructs that are used based on hypotheses and theories for testing a phenomenon.

The location on undertaking this research is Tax Offices in North Banjarmasin. The reason for choosing this research site is because it has a fairly low percentage of corporate taxpayer compliance by the end of 2018, only 58 percent, while the target of corporate taxpayer compliance is 80 percent. Therefore, researchers are interested in researching corporate taxpayer compliance in the province, and the importance of this study to be done because of the inconsistencies of the results of previous studies. The population in this study was 3,290 corporate taxpayers. The sampling method used is convenience sampling which refers to gathering information for those who are willing to become respondents. This research uses primary data. Primary data are obtained directly from respondents through a questionnaire.

Compliance with corporate taxpayers is a state of taxpayers who become their tax obligations and do their obtained tax rights. Tax compliance is also defined as reporting taxes on time according to the information needed and filling in the correct amount of tax owed. Indicators in this variable are business entities in which knowing taxation procedures, business entities which taking care of NPWP with their awareness, submission of proper tax returns is a reflection of compliant taxpayers, and tax payments must be voluntary.

Tax penalties are enforcement of regulations in taxation that are imposed for the creation of tax compliance. Indicator variables used in this study were adopted from instruments adopted by (Oladipupo \& Obazee, 2016). The indicators include tax penalty that is following tax regulations, fines as the penalty compliance fulfil the principle of justice, penalties as the sanction are imposed to create compliance taxpayers, and taxpayers who do not comply are subject to the applicable sanctions. 
Tax audit is the obedience or compliance of taxpayers in accomplishing the tax reporting system that is by filling out, calculating, collecting and deducting all taxes that comply with applicable law. Indicator variables in this study were developed by (Erani \& Meiliana, 2016). These indicators are regulations regarding the current tax audit procedures, tax audits can deter taxpayers, tax audits can improve taxpayer compliance, and tax audits are only being done by the authorities.

Awareness of taxpayers is where taxpayers recognize, respect, and obey the applicable tax provisions and have seriousness or desire to fulfil their tax obligations (Nurkhin, Novanty, Muhsin, \& Sumiadji, 2018). Indicator variables in this study were developed by (Siregar, 2017). The indicators are that the taxpayer is aware of the functions and benefits of the tax, the taxpayer is aware that performing tax compliance means to take part in the administration of the State, taxpayers are aware of tax payments following the specified time and the taxpayer is aware that the tax has been regulated by taxation law.

An intention is a form of behavior that is displayed which can be originated from within oneself and the environment (Siregar, 2017). Intention also becomes the basis for someone to behave, because someone in behavior won't happen without intention. Indicator variables in this study were developed by (Wanarta \& Mangoting, 2014).The indicators in this study are that taxpayers do not feel forced to pay taxes, taxpayers have the intention to always comply with Taxation Laws, taxpayers do calculations and report taxes purely on their own, and taxpayers intend to always comply with taxes because they realize that taxes are obligations that must be paid. The measurement scale of this study uses a Likert scale where this scale aims to measure the opinions, attitudes and perceptions of each individual to the group related to social phenomena. Overall the frequency of each indicator question of each variable in this study uses a scale of 1-7 i.e. Very Disagree (STS) was given a score of 1; Disagree (TS) given a score of 2; Somewhat Disagree (ATS) was given a score of 3; Neutral (N) score of 4; Quite Agree (AS) given a score of 5; Agree (S) given a score of 6; Very Agree Once (SSS) was given a score of 7 .

\section{Data analysis methods}

The data analysis technique used in this study is regression analysis, namely multiple linear regression analysis and Moderated Regression Analysis (MRA) with the help of SPSS version 16 software. Moderated Regression Analysis (MRA) is used because the regression equation contains interaction elements (the multiplication of two or more independent variables). The use of both of these analysis techniques is because they want to examine the effect of independent variables on the dependent variable by being moderated by moderating variable. The dependent variable of this research is corporate taxpayer compliance (CTC), the independent variables are tax penalties (TP), tax audits (TAU), taxpayer awareness (TAW) and the moderating variable is compliance intention (CI).

\section{Results and Discussions}

Descriptive statistics show a general description of the sample data that is processed following the research variables used. Descriptive statistics show the max, min, mean and standard deviation values.

From the results of the questionnaire obtained with the number of respondents was obtained 142 people, respondents 'answers are quite varied with the score of respondents' answers to corporate taxpayer compliance (Y), ranged from 20 to 28 . Overall, it can be seen that the standard deviation value is lower than the average value, so the level of diversity of values and data deviations in this study is relatively low.

Table 1: Descriptive statistic

\begin{tabular}{llllll}
\hline & $\mathrm{N}$ & Min & Max & Mean & Standard Deviation \\
\hline Tax Penalty & 142 & 20 & 28 & 25.01 & 2.172 \\
\hline Tax Audit & 142 & 20 & 28 & 24.42 & 2.239 \\
\hline Taxpayer Awareness & 142 & 18 & 28 & 24.74 & 2.431 \\
\hline Intention Compliance & 142 & 17 & 28 & 24.54 & 2.311 \\
\hline Taxpayer Compliance & 142 & 20 & 28 & 25.75 & 2.032 \\
\hline Valid N (listwise) & 142 & & & & \\
\hline
\end{tabular}

On the results of the validity test for Pearson's correlation coefficient, each item of this research statement shows the total score of the variable tax penalties, tax audits, taxpayer awareness, compliance intentions and corporate taxpayer compliance show a significant value at the 0.01 significance level. Thus, it can be said that each instrument indicator item in this study is valid. Furthermore, the reliability test results obtained from the Cronbach alpha for each variable are greater than 0.6. Then it can be concluded that the instrument for each variable is reliable.

The classical assumption test is done before testing the hypothesis. The classic assumption tests in this study include the normality test, multicollinearity test and heteroscedasticity test. Normality test in this study uses a histogram chart and Normal P-P. The results of the normality test in this study show a histogram chart in the form of a normal curve and a normal P-P chart showing the observation 
data plot around a diagonal line. It can be concluded that this research model is normally distributed. Then, for the multicollinearity test done by looking at the value of tolerance and VIF, the results of this study all tolerance values $>0.1$ and VIF < 10 . So, it can be summed up that the research model does not occur symptoms of multicollinearity. Heteroscedasticity test is done by looking at the plot between the predictive value of the dependent variable, ZPRED and the residual, SRESID. Based on the results, Scatterplot shows that the points spread in the bag and under the Y axis, and the points do not form a certain pattern. So, it can be concluded that there are no symptoms of heteroscedasticity.

Table 2: Summary of hypothesis testing results

\begin{tabular}{llll}
\hline Variable & t-Statistic & $p$-value & Decision \\
\hline SD & 4,308 & 0,000 & Supported \\
\hline PP & 3,305 & 0,001 & Supported \\
\hline KWP & 2,182 & 0,031 & Supported \\
\hline SD*NP & $-0,753$ & 0,214 & Not Supported \\
\hline PP*NP & 0,413 & 0,333 & Not Supported \\
\hline KWP*NP & -0.061 & 0,475 & Not Supported \\
\hline
\end{tabular}

The results of testing the first hypothesis demonstrate that the penalty sanctions have a positive effect on corporate taxpayer compliance. The results of this study are not supported by (Mahdi \& Ardiati, 2017) who explain that the tax penalty does not have a positive effect on corporate taxpayer compliance. However, this research is supported by research from (Siamena et al., 2017); (Siregar, 2017). Fines as a penalty are a form of punishment in the form of money for violating taxpayers, and this regulation has been written in taxation legislation, in other words, fines sanctions are a solution for taxpayers to comply with taxation.

The results of the second hypothesis testing show that the tax audit has a positive effect on corporate taxpayer compliance. This study is not supported by research undertaken by (Arifin \& Syafii, 2019) who explains that tax audits do not have a positive effect on corporate taxpayer compliance. However, this study is supported previous researches which are done by (Sunarto, 2018); and (Mandagi, Sabijono, \& Tirayoh, 2014) explains that tax audits affect taxpayer compliance. The existence of a tax audit by the tax authorities or the tax authorities can increase tax compliance, through efforts in law enforcement such as regular tax audits and the implementation of appropriate procedures. It will avoid the possibility of moral hazard that can be done by taxpayers in filling out the tax return.

The results of testing the third hypothesis illustrate that taxpayer awareness has a positive effect on corporate taxpayer compliance. The results of this study are not supported by (Nugroho, Andini, \& Raharjo, 2016) research which explains that taxpayer awareness does not have a positive effect on corporate taxpayer compliance. Nevertheless, this study is supported other previous researches like (Savitri \& Musfialdy, 2016); and (Kamil, 2015) who explain that taxpayer awareness is the taxpayer to comply with taxes based on his own volition.

The results of testing the fourth hypothesis in equation (3) (Table 2) about the interaction of compliance intention with tax penalty shows a negative coefficient and it is not significant (greater than 5\%). It can be concluded that $\mathrm{H} 4$ is not supported because the intention to comply is not able to moderate the positive effect of the penalty sanctions on corporate taxpayer compliance. In the results of this study explain that the intention is not able to moderate the effect of the tax penalty on corporate taxpayer compliance. The results of this study are in line with research done by (Oktaviani \& Nurhayati, 2015); (Suryani \& Yushita, 2017). Fine penalties make taxpayers will comply with tax regulations, so the intention is not able to become a moderating variable. These sanctions aim to increase tax compliance; this sanction is also assessed by taxpayers as an adverse matter. Therefore, taxpayers will comply with taxation to avoid penalties such as fines.

The results of the fifth hypothesis test in equation (3) (Table 2) about the interaction of intention compliance with tax audit shows that the coefficient is positive and not significant (greater than 5\%). It can be concluded that H5 is not supported because the intention to comply is not able to moderate the positive effect of tax audits on corporate taxpayer compliance. Unlike the case with the research conducted by (Oktaviani \& Nurhayati, 2015) that intention influences taxpayer compliance. But, this results of this study explain that the intention is not able to moderate the effect of tax audits on corporate taxpayer compliance. Tax audits that have executed regularly make taxpayers will comply with tax regulations, so the intention is not able to become a moderating variable. Tax audits are activities that process data, information and evidence carried out objectively and professionally based on tax audit standards. Besides, this examination will be a positive impetus for taxpayers to behave in compliance with taxes.

The results of the sixth hypothesis testing in equation (3) (Table 2) about the interaction of intention compliance with taxpayer awareness shows that the coefficient is negative and not significant (greater than 5\%). It can be concluded that H6 is not supported because the compliance intention is not able to moderate the positive influence of taxpayer awareness on corporate taxpayer compliance. This study is supported by research from (Oktaviani \& Nurhayati, 2015). The intention is not able to moderate the effect 
of tax audits on corporate taxpayer compliance, because of taxpayers already aware of their obligations as taxpayers, such as paying on time, aware of the functions and benefits of taxation. Therefore, because taxpayers are aware of the importance of this taxation, the intention cannot strengthen or weaken the influence of taxpayer awareness of corporate taxpayer compliance.

\section{Conclusions}

Overall, this study explains that the tax penalty can be a solution for taxpayers who violate tax regulations. Meanwhile, tax audits performed by the tax authorities have an important role to minimize the level of fraud committed by corporate taxpayers. Then, awareness of taxpayers here as an internal factor of taxpayers makes taxpayers aware of their obligations as taxpayers who must comply with tax regulations following applicable laws. However, the existence of compliance intentions as a moderating variable is not able to be a moderating variable. It is because that the applicable tax penalties and tax audits in the community have been going well and following applicable regulations, and the awareness of taxpayers to make taxpayers decide to comply with taxes.

The implications for the research are attribution theory can explain the behavior of taxpayers in complying with taxes influenced by two (2) factors, namely, external factors (penalty penalties and tax audits), and internal factors (awareness of taxpayers). Then, in the TRA which explains that the intention will arise when individuals have a great desire to do something. However, in this study, the adherence intention variable is unable to prove to be a moderating variable, so the impact on this TRA cannot be developed because it cannot explain the submission intention as a moderating variable. due to external factors and internal factors, namely financial penalties, tax audits, and awareness of taxpayers who make taxpayers compliant with taxes, so that the presence or absence of intent will continue to make taxpayers obedient to taxes.

The limitations of the study are those who fill out this questionnaire are representatives of corporate taxpayers or individuals who come to the tax office. Because researchers don't get permission from North Banjarmasin Primary Tax Office to distribute questionnaires directly to corporate taxpayers. Also, respondents who fill are expected to be respondents who are competent in their fields such as the field of taxation, so that questions on the questionnaire can be answered by all respondents and the results of the study can interpret the results better.

\section{References}

Adhiambo, O. J., \& Theuri, J. M. (2019). Effect of Taxpayer Awareness and Compliance Costs On Tax Compliance Among Small Scale Traders In Nakuru Town, Kenya. International Academic Journal of Economic and Finance, 3(3), 279-295.

Ajzen, I. (2002). Perceived Behavioral Control, Self-Efficacy, Locus of Control, and the Theory of Planned Behavior1. Journal of Applied Social Psychology, 32(4), 665-683.

Ajzen, I., \& Driver, B. L. (1992). Application of the Theory of Planned Behavior to Leisure Choice. Journal of Leisure Research, 24(3), 207-224. https://doi.org/10.1080/00222216.1992.11969889

Al- Maghrebi, M. S., Ahmad, R., \& Palil, M. R. (2016). Budget Transparency and Tax Awareness Towards Tax Compliance: A Conceptual Approach. South East Asia Journal of Contemporary Business, Economic and Law, 10(1), 95-101.

Arifin, S.B. \& Syafii, I. (2019). Penerapan E- Filing, E- Billing Dan Pemeriksaan Pajak Terhadap Kepatuhan Wajib Pajak Orang Pribadi Di Kpp Pratama Medan Polonia. Jurnal Akuntansi Dan Bisnis, 5(1), 9-21. https://doi.org/10.31289/jab.v5i1.1979

Bernard, O. M., Memba, F. S., \& Oluoch, O. (2018). Influence Of Tax Knowledge And Awareness On Tax Compliance Among Investors In The Export Processing Zones In Kenya. International Journal of Scientific Research and Management, 06(10), 728-733. https://doi.org/10.18535/ijsrm/v6i10.em01

Budiartha, I. N. W., \& Ketut, B. (2019). Effect Of Taxation Modernization On Tax Compliance. International Research Journal of Management, IT \& Social Sciences, 6(4), 207-213. https://doi.org/10.21744/irjmis.v6n4.683

Erani, I., \& Meiliana, R. (2016). Analisis Pengaruh Pelaksanaan Pemeriksaan Pajak Dan Penerapan Sanksi Perpajakan Terhadap Kepatuhan Wajib Pajak Badan Pada Kpp Di Wilayah Kota Bandar Lampung. Jurnal Bisnis Darmajaya, 02(01), 21-33.

Kamil, I. (2015). The Effect Of Taxpayer Awareness, Knowledge, Tax Penalties And Tax Authorities Services On The Tax Compliance: (Survey On The Individual Taxpayer At Jabodetabek \& Bandung). Research Journal of Finance and Accounting, 6(2), 104-112.

Keuangan, K. (2018). Rasio Pajak Indonesia Kalah Dibanding dengan Negara lainnya. Retrieved from https://databoks.katadata.co.id/datapublish/2018/12/12/rasio-pajak-indonesiakalah-dibanding-dengan-negara-lainnya

Mahdi, M. \& Ardiati, M. (2017). Pengaruh Kesadaran Wajib Pajak Dan Sanksi Pajak Terhadap Kepatuhan Wajib Pajak Orang Pribadi Pada Kantor Pelayanan Pajak Pratma Banda Aceh. Jurnal Ekonomi Manajemen Dan Akuntansi, 3(1), $22-31$. http://dx.doi.org/10.32672/jemsi.v3i1.246

Mandagi, C., Sabijono, H., \& Tirayoh, V. (2014). Pengaruh Pemeriksaan Pajak Terhadap Tingkat Kepatuhan Wajib Pajak Daban Dalam Memenuhi Kewajiban Perpajakannya Pada Kpp Pratama Manado. Jurnal EMBA, 2(3), 1665-1674.

Muhamad, A. \& P. 2019. (2019). Pengaruh Sosialisasi Perpajakan, Tarif Pajak, Sanksi Perpajakan, Dan Kesadaran Perpajakan Terhadap Kepatuhan Pelaporan Spt Tahunan Wajib Pajak Orang Pribadi. Jurnal Akuntansi \& Keuangan Daerah, 14(1), 6986.

Nugroho, A., Andini, R., \& Raharjo, K. (2016). Pengaruh Kesadaran Wajib Pajak Dan Pengetahun Perpajakn Wajib Pajak Terhadap Kepatuhan Wajib Pajak Dalam Membayar Pajak Penghasilan. Journal Of Acoounting, 2(2), 1-13. 
Nurkhin, A., Novanty, I., Muhsin, M., \& Sumiadji, S. (2018). The Influence Of Tax Understanding, Tax Awareness And Tax Amnesty Toward Taxpayer Compliance. Jurnal Keuangan Dan Perbankan, 22(2), 240-255.

Oktaviani, R., \& Nurhayati, I. (2015). Determinan Kepatuhan Wajib Pajak Badan Dengan Niat Sebagai Pemediasi Dari Perspektif Planned Behaviour Theory, 163-175.

Oladipupo, A. O., \& Obazee, U. (2016). Tax Knowledge, Penalties And Tax Compliance In Small And Medium Scale Enterprise In Nigeria. IBusiness, 8, 1-9. https://doi.org/10.4236/ib.2016.81001

Savitri, E., \& Musfialdy. (2016). The Effect Of Taxpayer Awareness, Tax Socialization, Tax Penalties, Compliance Cost At Taxpayer Compliance With Service Quality As Mediating Variabel. Procedia - Social and Behavioral Sciences, 219 , $682-687$. https://doi.org/10.1016/j.sbspro.2016.05.051

Siamena, E., Sabijono, H., \& Warongan, J. (2017). Pengaruh Sanksi Perpajakan Dan Kesadaran Wajib Pajak Terhadap Kepatuhan Wajib Pajak Orang Pribadi Di Manado. Jurnal Riset Akuntansi Going Concern, 12(2), 917-927.

Siregar, D. L. (2017). Pengaruh Kesadaran Wajib Pajak Dan Sanksi Pajak Terhadap Kepatuhan Wajib Pajak Orang Pribadi Pada Kantor Pelayanan Pajak Pratama Batam. Jurnal Paidagogeo, 2(3), 131-139.

Sunarto, A. M. (2018). Kepatuhan Wajib Pajak Terhadap Penerimaan Pajak Studi Kasus Pada Kpp Pratama Raba Bima Tahun $2012-$ 2015. Jurnal Akuntansi Dewantara, 2(1), 37-45. https://doi.org/10.29230/ad.v2i1.2220

Suryani, L., \& Yushita, A. N. (2017). Pengaruh Sikap, Norma Subjektif, Dan Kontrol Perilaku Persepsian Terhadap Kepatuhan Wajib Pajak Orang Pribadi Di Daerah Istimewa Yogyakarta Dengan Niat Mematuhi Pajak Sebagai Variabel Pemoderasi, 986(5), $1-20$.

Wanarta, F. E., \& Mangoting, Y. (2014). Pengaruh Sikap Ketidakpatuhan Pajak, Norma Subjektif, dan Kontrol Perilaku yang Dipersepsikan terhadap Niat Wajib Pajak Orang Pribadi untuk Melakukan Penggelapan Pajak. Tax \& Accounting Review, 4(1), 1-13.

Widuri, Retnaningtyas, Devina, Marta, Fransiska, Wati, \& Yulis. (2019). The Influence Of Penalties, The Trust On Authorities, And Teh Tax Audit Toward Tax Compliance. Journal of Economic and Business, 2(2), $218-229$. https://doi.org/10.31014/aior.1992.02.02.81 